\title{
IAMJ
}

INTERNATIONAL

AYURVEDIC

MEDICAL JOURNAL

\section{PHARMACOGNOSTICAL \& PHYTOCHEMICAL EVALUATIONS OF LEAVES OF AMARANTHUS SPINOUSUS LINN. IN CHHATTISGARH}

\section{$\underline{\text { Akhilesh Kumar Ratre }}^{1}$, Sandeep Shah Jureshiya ${ }^{2}$, Pravin Kumar Joshi ${ }^{3}$}

M.D. Scholar ${ }^{1,2}$, Professor\& H.O.D. ${ }^{3}$

Department of Dravyaguna, Govt. Ayurvedic College Raipur Chhattisgarh, India

Corresponding Author: akhileshkumar495001@gmail.com

https://doi.org/10.46607/iamj07p5062021

(Published online: September 2021)

Open Access

(C) International Ayurvedic Medical Journal, India 2021

Article Received: 31/08/2021 - Peer Reviewed: 11/09/2021 - Accepted for Publication: 12/09/2021

\section{Check for updates}

\section{ABSTRACT}

The present study aimed at detailed pharmacognostic evaluation of the crude drug, Morpho-anatomy of the leaves of A. spinosus Linn. was studied to aid pharmacognostic and taxonomic species identification using light and confocal microscopy, WHO suggested Physico-chemical determinations and authentic phytochemical measures. Amaranthus spinosus Linn. (Family Amaranthaceae), a very common Indian plant is known for its medicinal properties and is commonly known as 'spiny amaranth' or 'pig weed', "Kate wali Chaulai (Kanatabhajii)" in 'Hindi", cultivated throughout in India, Sri Lanka and distributed throughout the tropics and warm temperate regions of Asia, it has antidiabetic, antitumor, analgesic, antimicrobial, anti-inflammatory, spasmolytic, bronchodilator, hepato-protective, spermatogenic, anti-fertility, anti-malarial, antioxidant properties. The present study aims at developing a standardized profile of leaf, stem and root of A.spinosus which would be of immense use to identify and establish the authenticity of the plant A.spinosus

Keywords: A Spinosus. Linn., kanta cholai, Pharmacognostical, Phytochemical 


\section{INTRODUCTION}

IT has a rich cultural heritage of traditional medicines which chiefly comprised the two widely flourishing systems of treatments i.e. Ayurvedic and Unani systems since ancient times. Herbal medicines, also referred to as botanical medicine or phytomedicine, include herbs, herbal materials, herbal preparations and finished herbal products that contain parts of plants or other plant materials as active ingredients both Ayurveda, Unani and Siddha systems of medicine use plants and minerals as a source of drugs, plants are a major source of medicine. Amaranthus spinosus Linn. (Family Amaranthaceae) a very common Indian plant is known for its medicinal properties and is commonly known as 'spiny amaranth' or 'pig weed', "Kate wali Chaulai (Kanata bhaji)" in 'Hindi', cultivated throughout in India, Sri Lanka and distributed throughout the tropics and warm temperate regions of Asia, Amaranthus spinosus is used for the treatment of fever in traditional system of medicine. This plant is considered as one of the vegetables having a high concentration of antioxidant components and nutritional values due to the presence of fibres, proteins and high concentration of essential amino acids, especially lysine.

\section{Aim \& Objectives}

The present work aims to carry out Pharmacognostic, Phytochemical, and antioxidant activity leaves of $\mathrm{Am}$ aranthus spinous Linn. leaves.

\section{Material \& Methods}

In the present study, plant samples were collected from Chhattisgarh especially from the Bilaspur range of Chhattisgarh. It was selected based on availability and accessibility to study their pharmacognostic, and phytochemical analysis so that they can be studied in their drug form to avoid adulteration and maintain the purity of the drugs.

\begin{tabular}{|l|l|l|}
\hline Sl. No. & Sample & Plant name \\
\hline 1. & & Leaves of Amaranthus spinosus Linn.
\end{tabular}

Collection of the plant - Leaves of Amaranthus spinosus Linn. was collected in Bilaspur regions (19.10710N latitude and $81.9535^{\circ} \mathrm{E}$ longitude) of Chhattisgarh, India. Fresh leaves were collected from the field and washed; shade dried and packed in a paper bag for further Physico-chemical, phytochemical and antioxidant analyses.

Authentication of the Drug - A voucher specimen of the collected plant material was prepared, authenticated by Mr RS Jayasomu Senior Principal Scientist Head, RHMD and CSIR-NISCAIR institute and Drug Testing \& Research Laboratory, Raw Material Herbarium and Museum Delhi

\section{Instruments \& Chemicals}

For Pharmacognostic study - Compound binocular microscope (Olympus-CH20i model) with a built-in analogue camera (CMOF, 1.4 megapixels), camera lucida (prism type/plane type), stage micrometre, glass slides, coverslips, watch glass and other common glasswares were used during the microscopic study.
Solvents viz. formalin, glacial acetic acid, ethyl alcohol and reagents viz. safranin, glycerin, chloral hydrates were procured from Ranbaxy Fine Chemicals Ltd., Mumbai, India.

Macroscopic Characteristics - For morphological observations, leaves were used. The macro-morphological feature of leaves was observed under a magnifying lens and photographed using a digital camera (DSC W220, Sony Corp, Japan).

Microscopic Characteristics - The freehand section of the stem was taken and stained by the reagent safranine to confirm its lignification. Powder microscopy was also carried out and their specific diagnostic characters were recorded. Photomicrographs were obtained by observing the sections under a compound binocular microscope and the figures of the section were drawn with the help of Camera Lucida.

\section{Phytochemical study -}

Fluorescence analysis - The leaf powders were subjected to fluorescence analysis, as it is and also after treating separately with $1 \mathrm{~N} \mathrm{NaOH}, \mathrm{H}_{2} \mathrm{SO}_{4}, \mathrm{HNO}_{3}$, 
$\mathrm{NH}_{3}$, Iodine, Fecl, Acetic acid against normal and ultraviolet light (254 am \& $366 \mathrm{~nm}$ ).

Extraction of Plant materials: The stem bark of Amaranthus spinosus Linn. was dried in shade under normal environmental conditions and subjected to size reduction. Such powdered drug was charged into Soxhlet apparatus and extraction was carried out with Methanol \& water.

Physicochemical parameters - Leaves were studied for various physicochemical standards like foreign matter, loss on drying at $105^{\circ} \mathrm{C}$, total ash, acid-insoluble ash, alcohol soluble extractive and water-soluble extractive using standard methods.

For Phytochemical study: A CAMAG HPTLC system (Muttenz, Switzerland) equipped with a semi-automatic TLC applicator Linomat IV, twin trough plate development chamber, Win CATS software version 1.4.2. and Hamilton (Reno, Nevada, USA) Syringe $(100 \mu \mathrm{l})$. All chemicals, reagents and solvents used during the experimentation were of analytical grade were purchased from E. Merck Pvt. Ltd. (Mumbai, India).

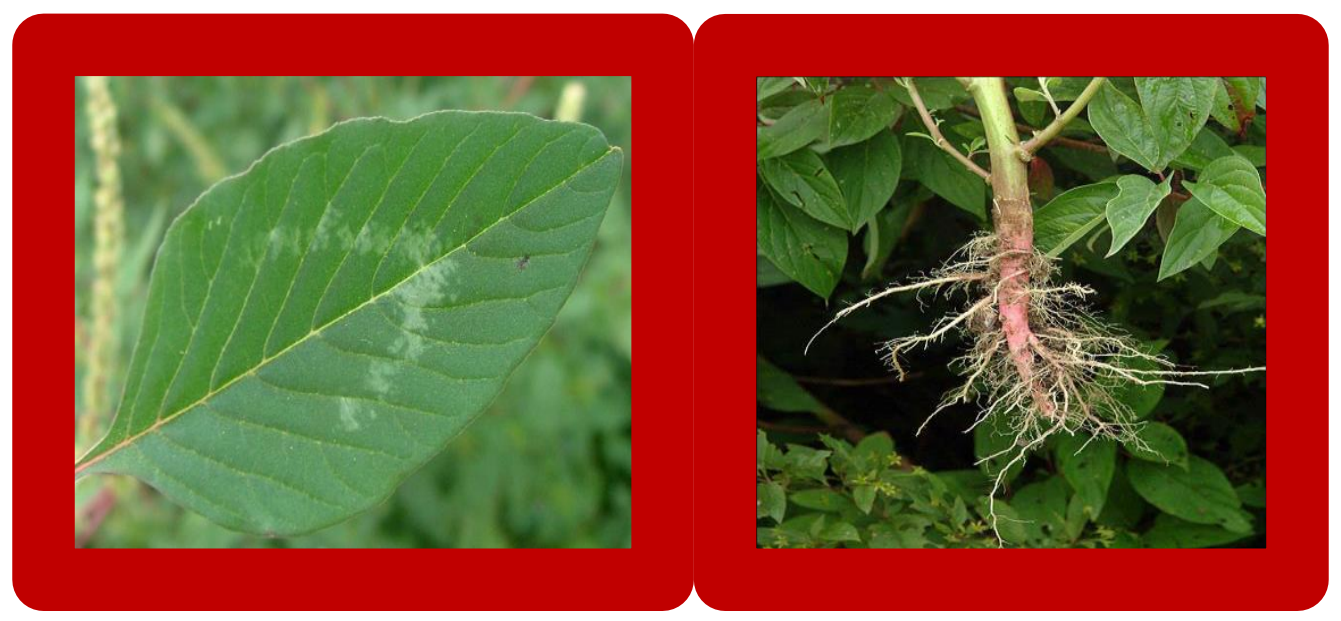

Leaf of Amaranthus spinosus Linn. The root of Amaranthus spinosus Linn.

\section{RESULT}

Pharmacognostic study For Amaranthus spinosus

Linn.

\section{a. Organoleptic charcters}

Colour: Dark greenish, dry brown

Odour: $\quad$ Characterstic odour

Stem colur: Light green, angular

Seed colour: Black

Taste: $\quad$ Sweet

b. Macroscopic characters

Part: $\quad$ Leaf

Shape: $\quad$ Curved

Colour: Greenish
Odour: Odourless

Taste: Tasteless

\section{c. Microscopic characters}

The diagnostic characters are:

Epidermis: It is uniseriate and cuticularised. It is wavy in outline.

Cortex: It is parenchymatous and bounded internally by a starch sheath layer.

d. Powder microscopy

Organoleptic characters

Colour: Greenish

Odour: Odourless

Touch: Smooth

Physiochemical analysis 
Table 1: Physicochemical characters of A. spinosus Linn. leaf.

\begin{tabular}{|l|l|l|}
\hline S.N & Physicochemical Parameters & Results \\
\hline 1. & Foreign Matter & Nill \\
\hline 2. & Total Ash (Average value in w/w) & $18.007 \%$ \\
\hline 3. & Loss on drying & $4.190 \%$ \\
\hline 4. & Acid Insoluble Ash (Average value in w/w) & $3.631 \%$ \\
\hline 5. & Alcohol Soluble extractive (Average value in $w / w)$ & $4.234 \%$ \\
\hline 6. & Water Soluble extractive (Average value in w/w) & $34.948 \%$ \\
\hline
\end{tabular}

\section{Fluorescence characters -}

The results of fluorescence analysis of the powdered leaf are presented in Table 2, which helps in detecting the presence of various constituents like phenolic com- pounds, flavonoids, steroids and other natural compounds based on different fluorescence with different chemical reagents. These studies help in the authentication of the plant.

Table 2: Fluorescence analysis of A.spinosus Linn. powder of leaf.

\begin{tabular}{|l|l|l|l|}
\hline Powder drug+ reagents & Normal light & UV Light254 nm & UV Light366nm \\
\hline Powder as such & Green & Green & Green \\
\hline Powder + $1 \mathrm{~N} \mathrm{HCL}$ & Colourless & Colourless & Colourless \\
\hline Powder + aqueous $1 \mathrm{~N} \mathrm{NNaOH}$ & Yellowish Green & Fluorescence Yellowish Green & Yellowish Green \\
\hline Powder + alcoholic $1 \mathrm{~N} \mathrm{NNaOH}$ & Green & Fluorescence Green & Fluorescence Green \\
\hline Powder $+50 \% \mathrm{HNO}_{3}$ & Light Yellow & Fluorescence Green & Fluorescence Green \\
\hline Powder $+50 \% \mathrm{H}_{2} \mathrm{SO}_{4}$ & Pale brown & Greenish brown & Brown \\
\hline Powder + Methanol & Dark green & Green & Green \\
\hline Powder + Water & Off-colour & Green & Green \\
\hline
\end{tabular}

\section{Preliminary phytochemical screening}

The results of Preliminary phytochemical screening in powder of leaf on Amaranthus spinosus Linn. are represented in

Table 3: Preliminary phytochemical screening of A.spinosus Linn. (powder of leaf.)

\begin{tabular}{|c|c|c|c|c|}
\hline Sr. No. & Plant constituent (Test) & Test/Reagent & Water & Alcohol \\
\hline 01 & Test for Steroids & Salkowski reaction Liebermann-Burchard test & Negative & Positive \\
\hline 02 & Test for Alkaloids & $\begin{array}{l}\text { Dragendorff's reagent } \\
\text { Mayer's reagent } \\
\text { Hager's reagent } \\
\text { Wagner's reagent }\end{array}$ & Negative & Positive \\
\hline 03 & Test for Tannins & $\begin{array}{l}\text { Ferric chloride test } \\
\text { Lead acetate test } \\
\text { Potassium dichromate }\end{array}$ & Positive & Positive \\
\hline 04 & Test for Flavonoids & Shinoda test & Positive & Positive \\
\hline 05 & Test for Carbohydrates & $\begin{array}{l}\text { Molish's test } \\
\text { Barfoed's test }\end{array}$ & Positive & Positive \\
\hline 06 & Test for Proteins & $\begin{array}{l}\text { Biuret test } \\
\text { Xanthoproteic test }\end{array}$ & Positive & Negative \\
\hline 07 & Test for Saponins & Foam test & Positive & Positive \\
\hline 08 & Test for Amino acid & Ninhydrin test & Positive & Negative \\
\hline 09 & Test for Reducing sugar & $\begin{array}{l}\text { Molisch's test } \\
\text { Barfoed's test }\end{array}$ & Positive & Positive \\
\hline 10 & Test for Monosacchrides & $\begin{array}{l}\text { Molisch's test } \\
\text { Barfoed's test }\end{array}$ & Positive & Negative \\
\hline
\end{tabular}




\begin{tabular}{|l|l|l|l|l|}
\hline 11 & Test for Pentose sugar & $\begin{array}{l}\text { Molisch's test } \\
\text { Barfoed's test }\end{array}$ & Negative & Positive \\
\hline 12 & Test for non-reducing sugar & $\begin{array}{l}\text { Molisch's test } \\
\text { Barfoed's test } \\
\text { Molisch's test } \\
\text { Barfoed's test }\end{array}$ & Negative & Negative \\
\hline 13 & Test for Hexose Sugar & - & Negative & Negative \\
\hline 14 & Test for Glycosides & Positive & Negative \\
\hline
\end{tabular}

\section{DISCUSSION}

Macroscopic characters are Amaranthus spinosus Linn. leaves Occurrence is Pieces, Shape-Rhomboid, Surface smooth, size $2-5 \mathrm{~cm}$ long and $1-3 \mathrm{~mm}$ thick. Power microscopy was colour-Brownish, OdourCharacterstatic odour, Taste Sweat, touch fine, Diagnostic characters are of the powder show, Cork cellsThick-walled, lignified, Stone cells- In groups, Crystals -Calcium oxalate, Starch Grains-Simple, round to oval, Fibre -Thick walled with pointed ends and narrow lumen.

- Foreign matter is directly related to the presence of impurities. Amaranthus spinosus Linn leaves are both drugs in the foreign matter is nill. The total Ash Value obtain are sample Amaranthus spinosus Linn $-18.007 \%$ w/w It indicates that the inorganic material has slightly fewer impurities.

- Moisture content ranged from the sample (Amaranthus spinosus Linn.) was $4.190 \%$ so, makes them a good source of hydration or glucose for the body as well as possessing then the ability to good health.

- Extractive values are primarily useful for the determination of exhausted or adulterated drugs Alcohol soluble extractive (A.S.E.) and. Water-soluble extractive (W.S.E.) values are an indication of the solubility of active principles of the plant. Alcohol soluble extractive values of given $4.234 \%$ w/w respectively. The result shows that the sample is LESS Alcohol soluble. Water-soluble extractive values are $34.948 \% \mathrm{w} / \mathrm{w}$ respectively. The sample has LESS soluble in alcohol. If we compare the A.S.E. and W.S.E. then the given sample is more soluble in alcohol.

\section{CONCLUSION}

The pharmacognostic and phytochemical studies were carried out on the leaf of Amaranthus spinosus Linn. The morphological, macroscopical and microscopic features observed during the study will be helpful for the proper identifications of these plant species. The Physico-chemical parameters are important analytical features and are constant within a range. The preliminary phytochemical analysis revealed the presence of different chemical constituents in crude extracts. This study will be helpful for quality control of single and polyherbal formulations. These chromatographic studies will be helpful as a tool in the quality control of the raw materials and finished products. This marker analysis of Phyto-constituents may also be helpful in phytoequivalence studies and other parameters can be established by studying the absorption, distribution, metabolism and elimination of pharmacologically active agents in the body.

\section{REFERENCES}

1. Agroforestry Database4.0 (Orwa et al. 2009) in Net.

2. http://www.biologydiscussion.com/plants/floweringplants/an-overview-on-family-Amaranthaceaebotany/19450.

3. Vegetable from natural surroundings and human health (google scholar)

\section{Source of Support: Nil \\ Conflict of Interest: None Declared}

How to cite this URL: Akhilesh Kumar Ratre et al: Pharmacognostical \& Phytochemical Evaluations Of Leaves Of Amaranthus Spinousus Linn. In Chhattisgarh. International Ayurvedic Medical Journal \{online\} 2021 \{cited September 2021\} Available from: http://www.iamj.in/posts/images/upload/3096_3100.pdf 